\title{
Cyclosporin A in skin samples from in vitro penetration studies may be assayed by a simple HPLC method
}

\author{
Luciana B. Lopes, Maria Vitória Lopes Badra Bentley*
}

Departamento de Ciências Farmacêuticas, Faculdade de Ciências Farmacêuticas de Ribeirão Preto, Universidade de São Paulo, Brasil

*Correspondence:

M. V. L. B. Bentley

Departamento de Ciências

Farmacêuticas

Faculdade de Ciências Farmacêuticas

de Ribeirão Preto, Universidade de São

Paulo

Av do Café $s / \mathrm{n}$,

14040-903, Ribeirão Preto, SP, Brasil

e-mail: vbentley@usp.br
A simple High Performance Liquid Chromatographic method with $U V$ detection was developed for quantification of Cyclosporin A (CysA) in skin samples after in vitro penetration studies. The peptide was recovered from two different layers of skin, the stratum corneum and the epidermis plus dermis ([E+D]), by vortex homogenization and bath sonication in an organic solvent (methanol). Recovery of CysA from skin was about $85 \%$, and CysA was estimated by HPLC using a RP-18 column, UV detection at $210 \mathrm{~nm}$ and acetonitrile:water $(67: 33 \mathrm{v} / \mathrm{v})$ as the mobile phase. The quantification limit was $150 \mathrm{ng} / \mathrm{mL}$. The assay was linear from 0.15 $500 \mathrm{Pg} / \mathrm{mL}$. The within-day and between-day assay precision and accuracy were studied at three concentration levels $(1,10$ and 20 $\mathrm{Pg} / \mathrm{mL}$ ). The coefficients of variation and deviation from the theoretical values were lower than 5\%. The method described has a potential application to in vitro penetration studies of Cys A using porcine skin as a biological membrane model.

\author{
Uniterms \\ - HPLC/ Cyclosporin \\ - A/ Skin \\ - In vitro penetration
}

\section{INTRODUCTION}

Cyclosporin A(CysA), a cyclic undecapeptide, is an effective inhibitor of both humoral and cell mediated immune responses by specifically and reversibly interacting with T lymphocytes (Borel, 1990). It has been used clinically for the prophylaxis and treatment of organ rejection in transplants as well as in the treatment of immune related disorders of skin such as psoriasis (Fisher et al., 1988; Linden et al., 1999; Lamelland et al., 2003). Its systemic administration has several shortcomings, often associated with drug variable pharmacokinetics, narrow therapeutic index, and large number of side effects (Duncan et al., 1990; Christians et al., 2000,).
Topical administration of CysA for treatment of skin diseases is interesting to directly target local lesions without major bioavailability problems, and to reduce the systemic side effects (Duncan et al., 1990; Choi et al., 1995; Boinpally et al., 2004). Several attempts have been made to increase CysA delivery to skin, which is hindered by the barrier function of the stratum corneum (SC). Penetration enhancers, physical techniques and drug delivery systems have been evaluated as strategies to increase CysA penetration in the skin (Duncan et al., 1990; Choi et al., 1995; Mizoguchi et al., 1992; Wang et al., 1997a; Wang et al., 1997b; Wang et al., 1998; Guo et al., 2000; Boinpally et al., 2004; Verma e Fahr, 2004).

The topical delivery of CysA requires the development of a robust and sensitive method to extract and quantify this 
drug in the skin in order to predict if adequate amounts of drug reaches viable layers of skin. To date, few studies involve the development of methods to quantify CysA in skin models (Wang et al., 1997a; Wang et al., 1997b; Wang et al., 1998; Guo et al., 2000; Boinpally et al., 2004). The present study aimed at developing a simple method to extracted CysA from $\mathrm{SC}$ and epidermis (E) plus dermis (D) of porcine ear skin ([E+D]), and to assay the drug using High Pressure Liquid Chromatography (HPLC). The suitability of the HPLC method to quantify CysA in homogenates of $\mathrm{SC}$ and $[\mathrm{E}+\mathrm{D}]$ was demonstrated.

\section{MATERIAL AND METHODS}

\section{Standard solutions and chemicals}

A $1 \mathrm{mg} / \mathrm{mL}$ standard solution of CysA in methanol was prepared and stored at $-5^{\circ} \mathrm{C}$. Working solutions $(0.1$ to $500 \mathrm{Pg} / \mathrm{mL}$ ) were prepared by appropriate dilutions with methanol and stored at $-5^{\circ} \mathrm{C}$. Solvents used for extraction and the mobile phase were of chromatographic grade (Omnisolve, Merck).

\section{Equipment and chromatographic conditions}

The Shimadzu liquid chromatography equipment consisted of a Model LC10 AD solvent pump, a Rheodyne injector fitted with a 20 PL loop, a Model SPD-10A variable wavelength UV detector operating at $210 \mathrm{~nm}$, a Model CTO-10A column oven at $60{ }^{\circ} \mathrm{C}$ and a model SCL-10A controller system. The separation was on a Lichrospher 100RP-18 column (5 Pm, Merck Darmstadt, Germany). The mobile phase was $67 \%$ acetonitrile and $33 \%$ water and the flow rate, $1 \mathrm{~mL} / \mathrm{min}$.

\section{Skin preparations}

The penetration of CysA in the skin was assessed using an in vitro model of porcine ear skin, as previously described. (Lopez et al., 2001). Briefly, the skin from the outer surface of a freshly excised porcine ear was carefully dissected (making sure that the subcutaneous fat was maximally removed), stored at $-20^{\circ} \mathrm{C}$, and used within a month.

\section{CysA recovery from porcine skin}

The absolute recovery of CysA from skin tissue was determined by spiking skin sections $\left(1.77 \mathrm{~cm}^{2}\right)$ with a CysA solution in methanol $(100 \mathrm{Pg} / \mathrm{mL})$. The spiked skin sections $(\mathrm{n}=7)$ were allowed to rest for 20 minutes. CysA was assessed in two different skin layers: stratum corneum and epidermis plus dermis. To separate the stratum corneum (SC) from the remaining epidermis (E) and dermis (D), skin sections were subjected to tape stripping. The skin was stripped with 15 pieces of adhesive tape, and the tapes containing the SC were immersed in $5 \mathrm{~mL}$ of methanol. The system was vortex stirred for $2 \mathrm{~min}$. The methanolic phase was filtered using a $0.45 \mathrm{Pm}$ membrane, and the resulting filtrate assayed for CysA by HPLC. The remaining $[\mathrm{E}+\mathrm{D}]$ was cut in small pieces, vortex mixed for $2 \mathrm{~min}$ in $2 \mathrm{~mL}$ of methanol, and homogenized by bath sonication for 30 minutes. The resulting mixture was then filtrated using 0.45 Pm membranes, and Cys A was determined in the filtrate by chromatographic assay.

\section{In vitro skin penetration}

The methodology developed for CysA quantification in porcine skin was used to determine CysA skin penetration after in vitro cutaneous penetration experiments. On the day of the experiment, the cleaned porcine ear skin was mounted in a Franz diffusion cell (diffusion area of $1.77 \mathrm{~cm}^{2}$; Hanson Research, Chatsworth, CA, USA), with the stratum corneum facing the donor compartment and the dermis facing the receptor compartment, which was filled with a receptor phase of $100 \mathrm{mM}$ phosphate buffer (pH 7.2) containing ethanol $(10 \%)$. Previous studies have used receptor phases containing up to $33 \%$ of ethanol to increase drug solubility in the receptor phase (Choi et al., 1995, Guo et al., 2000). The system was maintained at $37^{\circ} \mathrm{C}$ and under constant stirring. A hundred milligrams of a solution composed of CysA at $4 \%(\mathrm{w} / \mathrm{w})$ in propylene glycol $(\mathrm{n}=5)$ was applied to the surface of the stratum corneum (in the donor compartment), and the concentration of CysA in the SC and $[\mathrm{E}+\mathrm{D}]$ was determined at $12 \mathrm{~h}$ post-application.

At the end of the experiment, skin surfaces were thoroughly washed with distilled water to remove excess formulation. CysA was extracted from $\mathrm{SC}$ and $[\mathrm{E}+\mathrm{D}]$ using the methodology described above (in the item Cys $A$ recovery from porcine skin). The amounts of drug detected in $\mathrm{SC}$ and in $[\mathrm{E}+\mathrm{D}]$ were indicatives of drug penetration in the skin.

\section{Assay specifications}

Validation of a method is the process by which a method is tested by the developer or user for reliability, accuracy and preciseness of its intended purpose. Based on this, we evaluated several parameters to demonstrate that the analytical procedure is suitable for analyzing CysA in skin samples (ANVISA resolution number 899). 
Linearity responses were verified by using methanolic solutions of CysA in concentrations ranging from 0.1 to $500 \mathrm{Pg} / \mathrm{mL}$. The precision and accuracy of the method were tested in a within-day and between-day basis. For the determination of the within-day precision and accuracy, ten (10) CysA methanolic solution replicate aliquots at concentrations of 1,10 and $20 \mathrm{Pg} / \mathrm{mL}$ were analyzed. The between-day precision and accuracy were determined by analyzing 5 aliquots of the same CysA solutions on five consecutive days. The range, defined as the interval between the high and low levels of the analyte studied, was obtained based on the linearity.

The precision of the assay was calculated as the relative standard deviation (coefficient of variation, $\mathrm{CV}$ ), whereas the accuracy was calculated as the relative error of the mean, between expected and calculated concentrations, according to the following equation: Accuracy $(\%)=($ calculated mean - theoretical/theoretical) x 100 .

The sensitivity of the method was evaluated by determining the lower limit of quantification and the detection limit. The lower limit of quantification was set as the lowest CysA concentration that could be determined with adequate precision and accuracy, whereas the lower limit was the lowest CysA concentration that could be detected but not quantified under the stated experimental conditions (Causon, 1997, Santana et al., 2004). The detection and quantification limits were calculated by analyzing diluted solutions of CysA in concentrations ranging from $75-200 \mathrm{ng} / \mathrm{mL}$.

The selectivity of the method was verified by evaluating the interference of skin compounds and of the adhesive tape on the assay of CysA. Samples of control skin (treated with Milli Q water) were submitted to the same procedure to extract CysA, as described in the item CysA recovery from porcine skin. The homogenates of $\mathrm{SC}$ and $[\mathrm{E}+\mathrm{D}]$ were subject to HPLC assay.

\section{Calibration curves}

Calibration curves to assay CysA in skin samples were constructed by assaying methanolic solutions of the drug in concentrations ranging from 1 to $30 \mathrm{Pg} / \mathrm{mL}$.

\section{RESULTS AND DISCUSSION}

The therapy with CysA requires regular therapeutic drug monitoring and blood concentration guided dosing regimens have been recommended (Christians et al., 2000). CysA and its metabolites have been quantified in blood and other biological matrices by several methods, including the use of immunoassay kits, radioactive labeling of CysA and liquid scintillation assays. Good results have been obtained using HPLC (Kroschsorur et al., 1997, Safarcik et al., 2001). To date, few studies aimed at developing methodologies to assay CysA from skin samples.

Although HPLC methods have adequate specificity, several difficulties have been faced due to the characteristics of the peptide. HPLC-UV methods described have used appropriate reversed phase chromatographic columns maintained at relatively high temperatures $\left(70^{\circ} \mathrm{C}\right)$, necessary for adequate peak shaping. In general, the mobile phases used for HPLC assay are composed of high proportions of organic solvents, and long CysA retention times are observed (Kroschsorur et al., 1997, Husek, 1997). The low UV range absorption peak of the peptide (around $200 \mathrm{~nm}$ ) makes its detection difficult and susceptible to interferences (Taylor et al., 1998). The synthesis of fluorescent derivatives of CysA has already been studied in an attempt to increase the sensitivity and selectivity of HPLC assay for CysA (Fois and Ashley, 1989). However, to date, no efficient derivatization method has been demonstrated. In addition, skin samples presents proteins, lipids and other compounds that might interfere with CysA analysis, increasing its difficulty. Thus, a suitable method to extract CysA from skin samples and to assay this peptide with little interference is necessary.

The UV-HPLC method described in the present study has the advantage of a rapid and sensitive quantification of CysA retained in the skin. In addition, maintaining the chromatographic column at $60^{\circ} \mathrm{C}$ increases its working life. Figure 1 shows a typical profile of a CysA chromatogram.

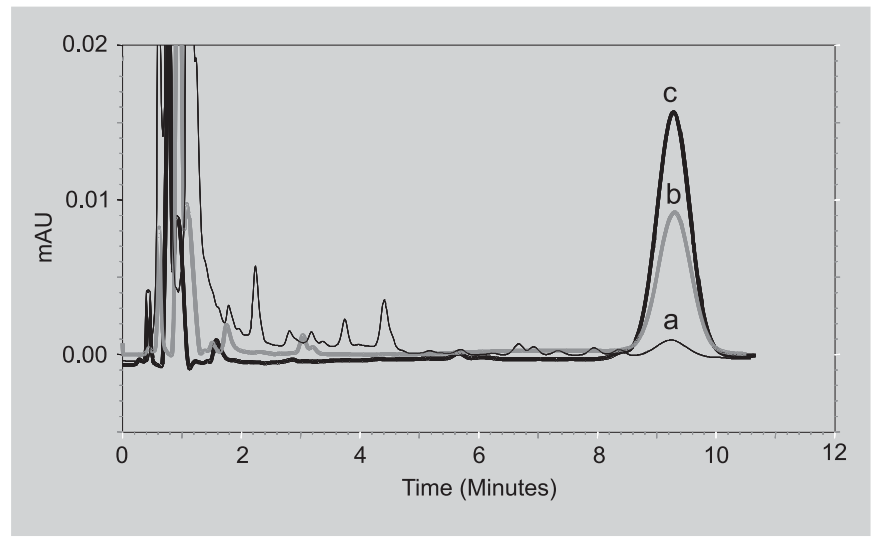

FIGURE 1 - Chromatograms of CysA standard solutions in methanol at concentrations of (a) $1 \mathrm{Pg} / \mathrm{mL}$, (b) $5 \mathrm{Pg} / \mathrm{mL}$ and (c) $10 \mathrm{Pg} / \mathrm{mL}$. CysA was assessed by HPLC using a RP-18 chromatographic column, mobile phase composed of acetonitrile and water $(67: 33 \mathrm{v} / \mathrm{v})$, flow rate of $1 \mathrm{~mL} / \mathrm{min}$ and UV detection at $210 \mathrm{~nm}$. 
Peak areas of the drug linearly correlated with concentrations in the range of $0.15-500 \mathrm{Pg} / \mathrm{mL}$. The equation for a typical calibration curve, obtained by the least squares linear regression was $y=26662 x+105.4$, $\mathrm{r}=0.999$.

The within-day precision and accuracy of the assay were obtained by sequential analysis of CysA solutions in methanol at three distinct concentrations $(1,10$ and $20 \mathrm{Pg}$ / $\mathrm{mL}$ ). The within-day assay coefficients of variation (CV) for CysA were lower than 5\% and all between-day assay coefficients of variation were below $3 \%$ (Table 1 ). The within-day and between-day assay accuracies were found to be 2.3 and $1.9 \%$ respectively for $1 \mathrm{Pg} / \mathrm{mL}, 3.1$ and $4.9 \%$ for $10 \mathrm{Pg} / \mathrm{mL}$, and 0.3 and $0.4 \%$ for $20 \mathrm{Pg} / \mathrm{mL}$.

The detection limit of the assay was $100 \mathrm{ng} / \mathrm{mL}$. The lowest concentration quantified by this method with acceptable precision and accuracy was $150 \mathrm{ng} / \mathrm{ml}$. This limit is adequate for the assessment of CysA retained in the skin, since the drug is lipophilic and it is expected to be retained within the $\mathrm{SC}$ and $[\mathrm{E}+\mathrm{D}]$ rather than to permeate across the skin.

The selectivity of the method was verified by evaluating the interference of compounds from skin and from the adhesive tape on the assay of CysA. Figure 2 shows chromatograms of homogenates of SC and [E+D] from control skin sections (treated with Milli Q water). The compounds of the skin and of the adhesive tape used for the tape stripping procedure did not interfere with the analysis of CysA. The HPLC method developed here proved to be selective since the retention time for other compounds present in the skin or in the adhesive tape, analyzed under the same chromatographic conditions of

TABLE I - Analysis of the precision and accuracy of the HPLC method for CysA

\begin{tabular}{lcc}
\hline $\begin{array}{l}\text { Nominal standard } \\
\text { concentration }(\mathbf{P g} / \mathbf{m L})\end{array}$ & $\begin{array}{c}\text { Precision } \\
(\mathbf{\%})\end{array}$ & $\begin{array}{c}\text { Accuracy } \\
(\mathbf{\%})\end{array}$ \\
\hline Within-day $(\mathrm{n}=10)$ & & \\
$0.15^{\mathrm{a}}$ & 4.1 & 3.0 \\
1 & 4.0 & 2.3 \\
10 & 4.9 & 3.1 \\
20 & 2.0 & 0.3
\end{tabular}

Between-day $(\mathrm{n}=5)$

$\begin{array}{ccc}1 & 2 & 1.9 \\ 10 & 2.8 & 4.9 \\ 20 & 1.9 & 0.4\end{array}$

$\mathrm{n}$, number of determination; $\mathrm{CV}$, coefficient of variation,

${ }^{a}$ lower limit of quantification

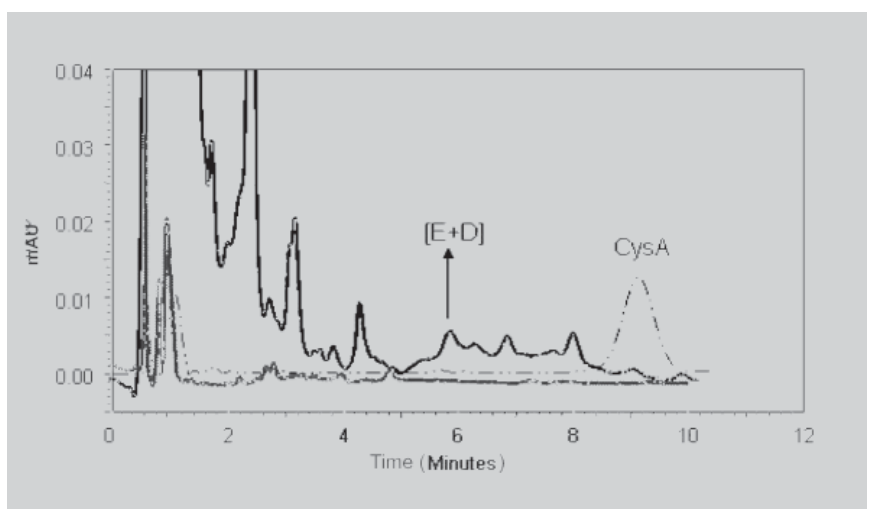

FIGURE 2 - Chromatograms referring to analyses of homogenates of SC (gray line) and [E+D] (bold black line) compared to the profile of a $5 \mathrm{Pg} / \mathrm{mL}$ CysA solution (dashed black line) to evaluate the selectivity of the method. Conditions: mobile phase: acetonitrile: water $(67: 33 \mathrm{v} / \mathrm{v})$; flow rate: $1 \mathrm{~mL} / \mathrm{min}$; UV detection: $210 \mathrm{~nm}$.

CysA analysis, was not similar to those obtained for CysA. The amount of CysA extracted from the skin (SC and [E+D]) corresponds to $85 \%$ of the spiked dose $(n=7)$. The method for CysA extraction from skin layers described in this paper resulted in a high recovery of the drug compared to other studies, which demonstrates its suitability for application on cutaneous penetration studies. Accordingly, the method reported by Wang et al. (1997a) resulted in an average $74 \%$ recovery of CysA from [E+D]. Moreover, the method of drug extraction described here also involves fewer steps and is less time-consuming than others described in the literature (Guo et al., 2000, Verma and Fahr, 2004). This method led, however, to the extraction of other compounds from the skin and from the adhesive tape together with CysA, but the HPLC method proved to be selective for the drug.

The methods developed for CysA quantification in skin samples by UV-HPLC demonstrated to be suitable for CysA assay in different skin layers after in vitro penetration studies. At $12 \mathrm{~h}$ post-application, $18.2 \pm 3.9 \mathrm{Pg} /$ $\mathrm{cm}^{2}(\mathrm{n}=5)$ of CysA was detected in the [E+D], and $48.8 \pm 6.5 \mathrm{Pg} / \mathrm{cm}^{2}$ in the SC (Figure 3).

In conclusion, the combined procedures of extraction and HPLC assay of CysA in the SC and $[\mathrm{E}+\mathrm{D}]$ is efficient in terms of drug recovery and rapid manipulation. In addition, the HPLC method has the required precision and accuracy. Considering the therapeutic advantages of topical administration of Cys A formulations in the treatment of cutaneous diseases, the proposed methodology for CysA assay in samples of different skin layers, from in vitro and even so in vivo studies, could be very important in the design 


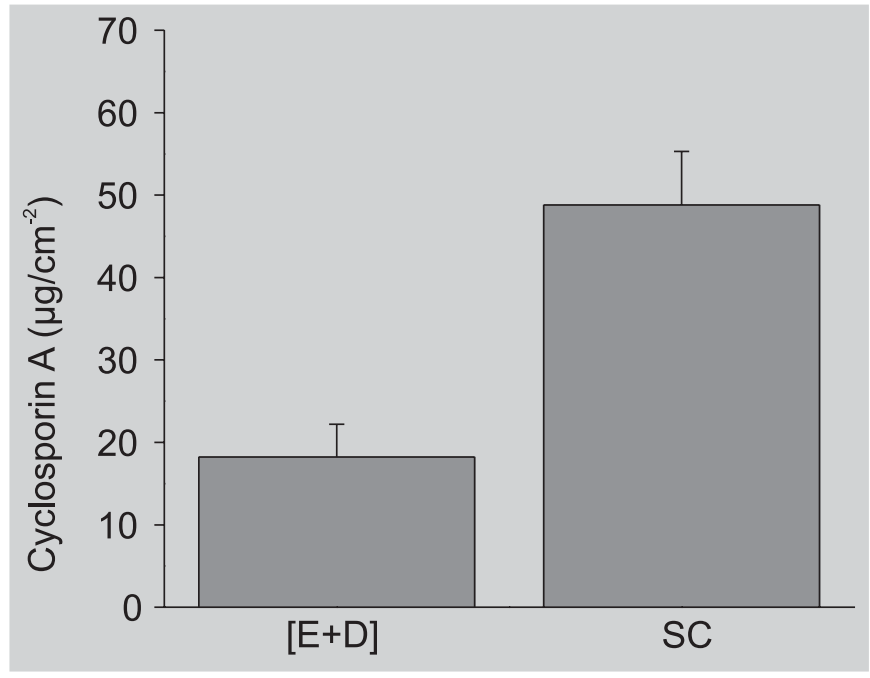

FIGURE 3 - Cyclosporin A in vitro penetration in the stratum corneum (SC) and epidermis plus dermis ([E+D]) at 12 hours post-application of a peptide solution in propylene glycol $(4 \% \mathrm{w} / \mathrm{w})$.

and evaluation of drug delivery using topical formulations.

\section{ACKNOWLEDGEMENTS}

We gratefully acknowledge the support of Conselho Nacional de Desenvolvimento Científico e Tecnológico (CNPq), Coordenação de Aperfeiçoamento de Pessoal de Nível Superior (CAPES) and Fundação de Amparo à Pesquisa do Estado de São Paulo (FAPESP), Brazil.

\section{RESUMO}

\section{Análise por CLAE da ciclosporina contida em amostras de pele provenientes de estudos de penetração cutânea in vitro.}

Neste estudo foi desenvolvido um método simples utilizando Cromatografia Líquida de Alta Eficiência (CLAE) com detecção no UV para quantificação de Ciclosporina A (CysA) em amostras de pele após estudos de penetração cutânea in vitro. O peptídeo foi extraído do estrato córneo e da epiderme sem estrato córneo + derme ([E+D]) através de agitação em vórtex e sonicação utilizando um solvente extrator (metanol). A recuperação da CysA de ambas as camadas da pele foi de $85 \%$, conforme estimado por CLAE utilizando coluna RP-18, detecção em $210 \mathrm{~nm}$ e fase móvel composta de acetonitrila e água $(67: 33, v / v)$. O limite de quantificação do peptídeo utilizando este método cromatográfico foi de 150 $\mathrm{ng} / \mathrm{mL}$. O método mostrou-se linear na faixa de 0,15$500 \mathrm{Pg} / \mathrm{mL}$. A precisão e exatidão intra e inter-ensaio foram avaliadas utilizando três concentrações distintas $(1,10$ e $20 \mathrm{Pg} / \mathrm{mL})$. Os valores de coeficiente de variação e o desvio do valor teórico foram inferiores a 5\%. O método descrito pode ser utilizado para determinação da CysA após estudos de penetração cutânea in vitro utilizando pele de porco como modelo de membrana.

UNITERMOS: CLAE. Ciclosporina A. Pele. Penetração cutânea in vitro.

\section{REFERENCES}

BOREL, J.F. Mechanism of action and rationale for cyclosporin A in psoriasis. Br. J. Dermatol., Oxford, v.122, suppl. 36, p.5-12, 1990.

FISHER, G.J.; DUELL, E.A.; NICKOLOLL, B.J.; ANNESLEY, T.M.; KOWALKE, J.K.; ELLIS, C.N.; VOORHEES, J.J. Levels Of cyclosporin In epidermis of treated psoriasis patients differentially inhibit growth of keraticocytes cultured in serum free versus serum containing media. J. Invest. Dermatol., Baltimore, v.91, n.2, p.142-146, 1988.

LINDEN, K.G.; WEINSTEIN, G.D. Psoriasis: current perspectives with an emphasis on treatment. Am. J. Med., New York, v.107, p.595-605, 1999.

LAMELLAND, F.; FELT-BAEYENS, O.; BESSEGHIR, K.; BEHAR-CHEN, F.; GURNY, R. Cyclosporin A delivery to the eye: a pharmaceutical challenge. Eur. $J$. Pharm. Biopharm, Amsterdam, v.56, p.309-318, 2003.

DUNCAN, J.I.; PAYNE, S.N.; WINFIELD, A.J.; ORMEROD, A. D.; THOMSON, A.W. Enhanced percutaneous absorption of a novel topical cyclosporin A formulation and assessment of its immunosuppressive activity. Br. J. Dermatol., Oxford, v.123, p.631-640, 1990.

CHRISTIANS, U.; JACOBSEN, W.; SERKOVA, N.; BENET, L.Z.; VIDAL, C.; SEWIG, K.; MANNS, M.P.; KIRCHNER, G.I. Automated, fast and sensitive quantification of drugs in blood by liquid chromatographymass spectrometry with on-line extraction: immunosuppressants. J.Cromatogr. B, Amsterdam, v.748, p.41-53, 2000. 
CHOI, H.K.; FLYNN, G.L.; AMIDON, G.L. Percutaneous absorption and dermal delivery of cyclosporin A. $J$. Pharm. Sci., Washington, v.84, n.5, 1995.

BOINPALLY, R.R; ZHOU, S.L;, DEVRAJ, G.; ANNE, P.K.; POONFRU, S.; JASTI, B.R. Iontophoresis of lecithin vesicles of cyclosporine A. Int. J. Pharm., Amsterdam, v.274, p.185-190, 2004.

MIZOGUCHI, M.; KAWAGUCHI, K.; OHSHUGA, Y.; IKARI, Y.; YANAGAWA, A.; MIZUSHIMA, Y. Cyclosporin ointment for psoriasis and topic dermatitis. Lancet, Londres, v.339, p.1120, 1992.

WANG, D.P.; LIN, C.Y.; CHU, D.L.; CHANG, L.C. Effect of various physical chemical properties on the transdermal delivery of cyclosporin through topical application. Drug Dev. Ind. Pharm., New York, v.23, n.1, p.99-106, 1997 a.

WANG, S.; KARA, M.; KRISHNA, T.R. Topical delivery of cyclosporin A coacervate using electroporation technique. Drug Dev. Ind. Pharm., New York, v.23, n.7, p.657-63, 1997b.

WANG, S.; KARA, M.; KRISHNA, T.R. Transdermal delivery of cyclosporin-A using electroporation. $J$. Control. Rel., Amsterdam, v.50, p.61-70, 1998.

GUO, J.; PING, Q.; SUN, G.; JIAO, C. Lecithin vesicular carriers for transdermal delivery of cyclosporin A. Int. J. Pharm., Amsterdam, v.194, p.201-207, 2000.

VERMA, D.D.; FAHR, A. Synergistic penetration enhancement effect of ethanol and phospholipid on the topical delivery of cyclosporin A. J. Control. Rel., Amsterdam, v.97, p.55-66, 2004.

LOPEZ, R.F.V.; BENTLEY, M.V.L.B.; DELGADOCHARRO, M.B.; GUY, R.H. Iontophoretic delivery of 5- aminolevulinic acid (ALA): effect of pH. Pharm. Res., New York, v. 18, p.311- 315, 2001.
BRASIL. ANVISA. Guia para validação de métodos analíticos e bioanalítico. Resolução ${ }^{\circ}$ 899, 29 de maio de 2003.

CAUSON, R. Validation of chromatographic methods in biomedical analysis. Viewpoint and discussion. $J$. Chromatogr. B, Amsterdan, v.689, p.175-180, 1997.

SANTANA, F.J.M.; CESARINO, E.J.; BONATO, P.S. New method for the chiral evaluation of mirtazapine in human plasma by liquid chromatography. J. Chromatogr. $B$, Amsterdan, v.809, p.351-356, 2004.

KHOSCHSORUR, G.; SEMMELROCK, H.I.; RODL, S.; AUER, S.; PETEK, W.; IBERER, F.; TSCHELIESSNIGG, K.H. Rapid, sensitive high performance liquid chromatographic method for the determination of cyclosporin A and its metabolites M1, M17 e M21. J. Chromatogr B, Amsterdam, v.690, p.367$72,1997$.

SAFARCIK, K.; BROZMANOVÁ, H.; BARTOS, V.; JEGOROV, A.; GRUNDMANN, M. Evaluation and comparison of therapeutic monitoring of whole blood levels of cyclosporin A and its metabolites in renal transplantation by HPLC and RIA methods. Clin. Chim. Acta, Amsterdam, v.310, p.165-171, 2001.

HUSEK, A. High-performance liquid chromatographic analysis of cyclosporin A and its oral solutions. $J$. Chromatogr. A, Amsterdam, v.750, p.217-24, 1997.

TAYLOR, P.; JONES, C.E.; MARTIN, P.T.; LYNCH, S.V.; JOHNSON, A.G.; POND, S.M. Microscale highperformance liquid chromatography-electrospray tandem mass spectrometry assay for cyclosporin A in blood. $J$. Chrom. B, Amsterdam, v.705, p. 189-294, 1998.

FOIS, R.A.; ASHKEY, J.J. Synthesis of a fluorescent derivative of cyclosporine A for high-performance liquid chromatography analysis. J. Pharm. Sci., Washington, v.80, n.4, 1989.

Recebido para publicação em 03 de dezembro de 2004. Aceito para publicação em 15 de junho de 2005. 